\title{
PENINGKATAN KOMPOTENSI GURU MELALUI PELATIHAN MEMBUAT RPP KURIKULUM 2013 DENGAN MENGAKTIFKAN KKG GAH KECAMATAN TEMBUKU KABUPATEN BANGLI TAHUN 2018
}

\author{
Oleh : \\ Ida Bagus Arnika \\ Kantor Kementerian Agama Kabupaten Bangli \\ bagusarnika@gmail.com
}

Diterima 11 Oktober 2018, direvisi 6 Pebruari 2019, diterbitkan 29 Maret 2019

\begin{abstract}
The aims of this study is to improve the teacher's potential through training in making lesson plan of curriculum 2013 at the GAH KKG in Tembuku District, and in Bangli Regency. This study is School Action Research (PTS) using two cycles design and each cycle consists of four stages, namely: planning, action, observation, and reflection. A measurement technique in the form of test is used to obtain a quantitative data and an observation sheets is used to obtain a qualitative data. The data was analyzed by using descriptive analysis. The subjects in this study were 30 Hindu Religion Teachers, in GAH KKG with less moderate and capable criteria. The object of this study is the ability of teachers to make a lesson plan of 2013 Curriculum to manage classroom learning. Furthermore, based on the results of this study first, at the end of the first and second cycles there was an increase in the average results of teacher's potential through training. The results of the previous training at 70.00 to 87.60. Then, in the third cycle the professional level of the teacher achieved good grades. Second, it turned out that the increase of teacher's potential through training by activating the GAH KKG in Tembuku district and in Bangli regency in 2018 showed very significant results from the initial conditions before receiving the training.
\end{abstract}

Keywords: Teacher's Potential Enhancement Through Training Making 2013 Curriculum RPP by Activating the KKG.

\section{PENDAHULUAN}

Peranan guru begitu sentral dalam upaya peningkatan mutu pendidikan di Indonesia. Hal ini didasari pemikiran bahwa titik berat pembangunan pendidikan diletakkan pada peningkatan mutu setiap jenjang dan jenis pendidikan juga akan sangat dipengaruhi oleh profesionalisme guru, sehingga kompetensi guru perlu terus ditingkatkan atau dengan kata lain kinerja guru di tuntut harus maksimal. Pembangunan dibidang pendidikan telah diupayakan dengan perbaikan kurikulum, pemenuhan sarana dan prasarana pendidikan, sistem evaluasi, pengembangan bahan ajar, pelatihan guru dan tenaga pendidik, serta kerjasama dengan Komite Sekolah.

Kurikulum 2013 mengalami perubahan sangat pesat sejak dilaksanakan pertama kali tahun 2014. Perubahan yang paling mendasar ada pada diundangkanya Peraturan Menteri Pendidikan dan Kebudayaan Republik Indonesia No 20 tahun 2016 tentang Standar kompetensi Lulusan, Permendikbud nomor 21 tahun 2016 tentang Standar Isi, Permendikbud nomor 22 tahun 2016 tentang Standar Proses, Permendikbud Nomor 23 tahun 2016 tentang 
Santandar Penilaian dan Permendikbud Nomor 24 tahun 2016 tentang Standar muatan Kurikulum KI-KD. Berdasarkan perubahan tersebut guru agama Hindu di Kecamatan Tembuku yang berjumlah 50 orang mendapat pelatihan Kurikulum 2013 tahun 2018 sebanyak 20 orang sedangkan lagi 30 orang belum mendapat pelatihan dari sejumlah SD wilayah binaan sebanyak 29 sekolah.

Berdasarkan hasil supervise pengawas pendidikan agama Hindu ditemukan keluhan guru agama Hindu sangat minim pemgetahuan tentang perubahan Kurikulum 2013. Terutama bagi mereka yang belum pernah diberikan sosialisasi Kurikulum 2013, Guru sangat hawam dengan perangkat pembelajaran Kurikulum 2013 edisi revisi. Memperhatikan dan mempertimbangkan kenyataan tersebut pengawas Sekolah melakukan trobosan sesuai tugas pokok dan pungsinya berupaya mengadakan rembug kecil dengan pengurus KKG dan Koordinator Pengawas. Dari hasil pembicaraan tercetus segera melakukan upaya peningkatan kemampuan guru binaan dengan melakukan pelatihan membuat RPP Kurikulum 2013 edisi revisi. Ketua KKG sangat sepakat untuk melakukan pertemuan pelatihan dengan asumsi dapat memberikan pengetahuan baru terkait perubahan Kurikulum 2013. Pengurus KKG menginnginkan bahwa narasumber pelatihan adalah Bapak Koordinator Pengawas dengan alasan sudah melakukan kunjungan kelas dan sering mendapat pelatihan penyususunan Buku Pasraman Formal tingkat Nasional yang menggunakan Kurikulum 2013. Beliau sudah sering ikut pelatihan yang dilatih oleh narasumber dari Puskur.

Peningkatan kemampuan/kompetensi guru dalam membuat RPP memperlancar pelaksanaan proses belajar mengajar bagian dari usaha peningkatan mutu guru, dimana guru mempunyai peranan yang sangat penting yaitu sebagai perencana, pelaksana dan dinamisator bahan ajaran yang dilaksanakan sesuai dengan tingkat dan perkembangan peserta didik melalui penguasaan didaktik dan metodik. Namun, peran atau kemampuan guru dewasa ini masih dinilai jauh dari harapan, sehingga harus ada upaya pelatihan Kurikulum. Banyak upaya untuk meningkatkan kemampuan profesional guru. Salah satu kegiatan yang dapat dilakukan adalah dengan sistem pembinaan dan pelatihan profesionalisme guru dalam kegiatan KKG.

Saat pelaksanaan proses pembelajaran guru wajib mempersiapkan Adminitrasi dan prangkat pembelajaran termasuk Rencana Pelaksanaan Pembelajaran ( RPP ). Berdasarkan hasil supervisi kelas dapat disimpulkan bahwa guru yang belum mampu menyusun RPP diakibatkan belum terbiasa dilatih untuk rajin membaca peraturan yang diimplementasikan pada persiapan mengajar. Guru belum mampu menysusun RPP yang standar karena jarang mendapat pendidikan dan pelatihan untuk persamaan persepsi. Disamping itu juga guru kurang proaktif mencari tahu tentang perkembangan pendidikan. Termasuk pengawas jarang mendapat pelatihan membina guru. Berdasarkan kenyataan itu maka pengawas berinisiatif melakukan pembinaan dan pelatihan berdasarkan hasil temuan dan tindaklanjut kajian hasil pengawasan dalam bentuk karya tulis Penelitian Tindakan Sekolah. Untuk meningkatkan kemampuan guru dalam membuat RPP 2013 melalui Pembinaan dan Pelatihan sangat penting dan mendesak dilaksanakan. Terbatasnya waktu serta biaya maka pelaksanaan Peningkatan Kompotensi Guru Melalui Pelatihan Membuat RPP Kurikulum 2013 dengan mengaktifkan KKG Pendidikan Agama Hindu tingkat SD di Kecamatan Tembuku Kabupaten Bangli tahun 2018 karena semua sekolah wajib menggunakan Kurikulum 2013. KKG merupakan tempat paling tepat sebagai bengkel kerjanya guru untuk meningkatkan kompetensi menghadapi permasalahan tentang RPP Kurikulum 2013 yang merupakan perangkat pembelajaran. 
Bagi guru belum memahami standar Permendikbud No 22 Tahun 2016 tentang Standar Proses Pendidikan Dasar dan Menengah, akan mengahadapi permasahan tentang kualitas kemampuan guru membuat perangkat pembelajaran. Beberapa identifikasi permasalahan yang dihadapi guru antara lain:

1. Rendahnya kemampuan guru dalam menyusun Indikator Pencapaian Kompetensi.

2. Rendahnya kemampuan guru dalam menyusun silabus.

3. Rendahnya pemahaman guru dalam membuat RPP Kurikulum 2013.

4. Rendahnya kemampuan/kompetensi guru membuat RPP sesuai Permendikbud No 22 tahun 2016.

5. RPP Kurikulum 2013 yang dipergunakan guru di Kecamatan Tembuku Kabupaten Bangli masih berbeda-beda pemahaman.

6. RPP yang dipahami sebelumnya belum menunjukan karakteristik sekolah sesuai harapan Kurikulum 2013.

7. Kurang Aktifnya KKG Pendidikan Agama Hindu tingkat SD di Kecamatan Tembuku Kabupaten Bangli untuk meningkatkan Kompetensi guru.

Begitu banyaknya permasalahan yang dihadapi guru namun yang paling mendasar menjadi pokok permasalahan untuk diteliti adalah rendahnya kemampuan/kompetensi guru dalam membuat RPP Kurikulum 2013 dengan mengaktifkan KKG. Sehingga dapat dirumuskan permasalahan "Apakah dengan pelatihan di KKG dapat meningkatkan kemampuan Guru Agama Hindu SD Kecamatan Tembuku dalam membuat RPP Kurikulum 2013?" Proses pembelajaran akan berjalan efektif dan menyenangkan jika perencanaan dari persiapan mengajar memenuhi standar proses.

Tujuan kegiatan ini (a). Untuk meningkatkan kompetensi Guru Agama Hindu tingkat SD di Kecamatan Tembuku Kabupaten Bangli dalam membuat RPP Kurikulum 2013. (b). Untuk mengaktifkan KKG Guru Pendidikan Agama Hindu tingkat SD di Kecamatan Tembuku Kabupaten Bangli dalam mempersiapkan perangkat Pembelajaran.

Berdasarkan PTS dari Banmbang Rahono (2003:5) bahwa kemampuan Guru membuat RPP merupakan kunci keberhasilan. Sekolah yang memiliki guru dengan komitmen tinggi terhadap peningkatan mutu guru akan cepat berkembang karena kunci keberhasilan sangat tergantung kinerja gurunya. Menurut Pidarta (1990) dalam Pelangi (2005:23) guru merupakan kunci kesuksesan sekolah dalam mengadakan perubahan. Kegiatan meningkatkan dan memperbaiki program, perencanaan dan pelaksanaan serta evaluasi dari proses pembelajaran kesuksesanya terletak pada kesungguhan, kreatifitas, inovasi, komitmen, rasa ingin tahu untuk mengembangkan kompetensinya, merupakan cerminan dari karakter diri guru yang ditularkan pada siswanya.

Menurut pendapat tersebut bahwa semua warga sekolah memegang peranan penting untuk mendukung keberhasilan peningkatan mutu pendidikan. Peranan KKG akan terwujud untuk mampu memecahkan masalah guru dalam upaya meningkatkan kompetensinya tidak terlepas dari dukungan warga sekolah. Maka setiap sekolah memiliki kewajiban untuk memotivasi para guru agar berperan aktif dalam KKG dan MGMP. Karena setiap persoalan dan permasalahan akan dapat dipecahkan di KKG dan MGMP dengan mengundang para narasumber yang berkompeten dibidangnya masing-masing untuk mensukseskan program Kurikulum 2013. Semua guru belum paham terhadap pemberlakuan Kurikulum 2013 sehingga perlu sering dibahas dan dilatih dari pembuatan RPPnya sampai penerapanya dalam kegiatan belajar mengajar di kelas.

Melihat kenyataan tersebut peneliti berinisiatif untuk melakukan penelitian yang dituangkan ke dalam judul penelitian" Peningkatan Kompotensi Guru melalui 
Pelatihan Membuat RPP Kurikulum 2013 Dengan Mengaktifkan KKG GAH SD di Kecamatan Tembuku Kabupaten Bangli Tahun 2018".

\section{Metodologi Penelitian}

Metode yang dipakai untuk mengumpulkan data penelitian ini adalah wawancara dan observasi. Wawancara adalah untuk memperoleh informasi yang diperlukan untuk melengkapi data dalam penelitian, maka wawancara sangat penting diperlukan untuk kelancaran proses penelitian (Singarimbun, 1995:175). Teknik wawancara/Interview adalah pecakapan langsung antara pewawancara dengan yang diwawamcarai.

Metode wawancara digunakan dalam penelitian untuk tujuan tertentu, agar mendapat keterangan atau pendirian secara lisan dari respondent, dengan bercakap-cakap atau bertatap muka langsung kepada orang yang diwawancarai itu (Koentjakraningrat, 1977:162). Wawancara sebagai metode dipergunakan untuk mendapatkan data-data, keterangan-keterangan, pendirian-pendirian mengenai pokok masalah supaya hasil yang didapatkan mencakup keseluruhan. Mengenai wawancara mendalam dilakukan terhadap informan tertentu, yakni wawancara kepada orang-orang yang dianggap tahu dan menguasai permasalahan yang sedang diteliti. Untuk mengarahkan pembicaraan pada pokok permasalahan dipergunakan pedoman wawancara.

Suatu pedoman wawancara, tentunya harus benar-benar dapat dimengerti oleh pengumpul data, sebab dialah yang akan menanyakan dan menjelaskan pada responden (Fasial, 2001:52).

Daftar wawancara dibuat berupa pertanyaan-pertanyaan dipegang oleh peneliti dalam bentuk wawancara antara peneliti dengan subjek yang diteliti dan mengisi daftar wawancara pihak peneliti (Sigit, 2001:100). Pedoman wawancara berguna untuk menghindari kehabisan bahan pertayaan.
Wawancara akan lancar jika dapat dirumuskan pertanyaan-pertanyaan dengan sempurna, dan hal itu mata tergantung pada sisi pertanyaan. Isi pertanyaan sebagai pedoman wawancara erat hubunganya dengan pengetahuan peneliti tentang isi pokok permasalahan pada pedoman wawancara yang dipergunakan.

Indikator keberhasilan penelitian ini adalah pada siklus I guru-guru dianggap berhasil apabila mencapai peningkatan kemampuan menyusun memahami RPP Kurikulum 2013 dari sebelumnya. Pada siklus II diharapkan kemampuan guru meningkat pemahamnya terhadap Rencana Pelaksanaan Pembelajaran Kurikulum 2013 dan mampu mengisi format serta nilainya meningkat. Pada siklus III para guru diharapkan sudah mampu tampil menyajikan RPP Kurikulum 2013 untuk diterapkan dalam kelas dan nilainya mengalami peningkatan. Sehingga diawal memahami konsep pembuatan RPP Kurikulum 2013, membuat dan mengisi format serta menguasai langkah-langkah pembelajaran RPP Kurikulum 2013 pada PBM. Pemberian tindakan achievement motivation training dan peer teaching ini efektif jika para guru mampu menyusun rencana pembelajaran yang sesuai dengan tujuan pembelajaran serta menyajikan pembelajaran dengan menyenangkan dapat mencapai poin baik. Berdasarkan peraturan dari Direktur Jendral Pendidikan Tinggi Depdiknas, 2007, poin penilaian untuk kemampuan pengelolaan pembelajaran untuk guru adalah:

Skor 1 = Tidak Baik nilai 49 ke bawah

Skor $2=$ Kurang Baik nilai 50-60

Skor $3=$ Cukup 61-75

Skor $4=$ Baik 76-85

Skor 5 = Sangat baik 86-100

Metode yang digunakan dalam penelitian ini adalah deskriptif kualitatif, yaitu data yang diperoleh dihimpun dan dianalisa sesuai keadaan dan situasi yang sebenarnya dengan tolak ukur ketentuan dan undang-undang yang berlaku, yaitu dengan cara menghimpun 
informasi secara mendalam mengenai keadaan dan kondisi sebenarnya dalam pemberian tindakan pada kegiatan KKG .

\section{HASIL DAN PEMBAHASAN Hasil dan Pembahasan}

Hasil analisis data menunjukkan kegiatan KKG dapat meningkatkan kemampuan membuat RPP Kurikulum 2013 pada Guru Agama Hindu tingkat SD Kecamatan Tembuku Kabupaten Bangli. Tahapan dilakukan evaluasi tindakan yang telah dilaksanakan, meliputi evaluasi mutu, jumlah dan waktu dari setiap jenis tindakan. Refleksi siklus bertujuan untuk memperoleh kesepakatan tindakan pada siklus berikutnya sehingga pelaksanaan tindakan berikutnya menjadi lebih baik. Berdasarkan data hasil evaluasi dan observasi kegiatan KKG guru agama Hindu tingkat SD di Kecamatara. Tembuku Kabupaten Bangli selama proses pelatihan berlangsung, dimana hasil yang dicapai hasil tiap siklus mengalami peningkatan. Dari hasil pengamatan selama siklus I Siklus II dan siklus III berlangsung dan berdasarkan hasil analisis, ada beberapa hal yang perlu mendapat penekanan, antard lain:

1. Beberapa guru masih belum mampu menunjukan aktivitas secara maksimal, terbukti masih sebagian guru belum memiliki kreatifitas dan inovasi untuk mengerjakan pelatihan pengembangan RPP Kurikulum 2013 yang inovatif dan berkarakter sebagai pegangan guru dalam mengajar.

2. Beberapa guru belum mampu membuat menguasai konsep dan format RPP Kurikulum 2013 secara mandiri terutama yang mendapat predikat kurang baik dan cukup, terbukti dari hasil pengisian format RPP masih banyak perluc. disempurnakan.

3. Kesiapan guru untuk memahami konsep masih kurang, terbukti dari hasil tes yang diberikan masih banyak guru yang kurang tepat/ belum sempurna.
4. Kurang luasnya pemahaman tentang pembuatan RPP Kurikulum 2013 sehingga saat diskusi belum berani menyalahkan atau membenarkan hasil pelatihan.

5. Rata-rata hasil pelatihan untuk peningkatan kemampuan guru membuat RPP belum sepenuhnya mencapai kreteria ketuntasan minimal dengan predikat baik.

6. Pelatihan di siklus I, II dan III sudah dapat dikatakan meningkat karena nilai perolehan skor dan predikatnya meningkat terutama kemampuan dalam memahami konsep, mengisi format dan mengimplementasikan RPP Kurikulum 2013 walaupan perlu disempurnakan.

\section{Hasil Penilaian Masing-Masing Siklus} Hasil Siklus I

Pada siklus I dari 30 guru agama Hindu yang dilatih dan dilakukan penilaian ternyata yang mendapat predikat kurang baik sebanyak 6 orang, predikat cukup 18 orang dan predikat baik 6 orang.

\section{Hasil Sklus II}

Kondisi yang dialami oleh guru agama Hindu tingkat SD Kecamatan Tembuku Kabupaten Bangli pada siklus I dapat dilihat perubahanya. Setelah diberikan pemahaman praktek pengisian format RPP kurikulum 2013 terjadi peningkatan yang signifikan. Dari awalnya di siklus I ada mendapat predikat kurang baik di siklus II menjadi tidak ada yang kurang baik. Hasil penilaian dari 30 orang guru yang dilatih 13 orang mendapat nilai cukup, 11 orang mendapat predikat baik dan 6 orang mendapat predikat sangat baik.

\section{Hasil Siklus III}

Pada siklus ketiga juga mengalami penigkatan yang sangat signifikan walaupun belum semuanya memmenuhi ketentuan persyaratan minimal dengan predikat baik. Perkembangan kemampuan guru meningkat tajam, dari 30 
guru yang dilatih dan dinilai hasilnya sebagai berikut : 5 orang mendapat predikat cukup, 16 orang mendapat predikat baik dan 9 orang mendapat predikat sangat baik.

Hasil setiap siklus dalam penelitian ini senantiasa mengalami peningkatan walaupun belum semuanya memenuhi kreteria ketuntasan minimal dengan predikat baik. Baru satu tahapan dilaksanakan pelatihan pembuatan dan penerapan Kurikulum 2013 sudah mengalami peningkatan kompetensi guru yang sangat menggembirakan. Sehingga semua peserta pelatihan meminta pembinaan dan pelatihan secara swakarsa dan mandiri dalam wadah KKG disemua tingkatan sekolah perlu terus dilanjutkan. Bahkan tindaklanjut dari pengawas agar senantiasa dilakukan observasi kelas dan refleksi saat guru mengajar di kelas.

\section{KESIMPULAN}

Berpijak atas hasil analisis data hasil penelitian dapat disimpulkan bahwa kegiatan pembiaan dan pelatihan KKG dapat meningkatkan kemampuan Guru Agama Hindu tingkat SD di Kecamatan tembuku Kabupaten Bangli dalam membuat RPP Kurikulum 2013 mencapai nilai baik. Hal ini didukung oleh peningkatan tiap siklus dari awalnya ada yang mendapat nilai kurang baik menjadi cukup dan akhirnya terus meningkat ada yang mendapat nilai sangat baik, baik dan cukup. Pada siklus ketiga juga mengalami penigkatan yang sangat signifikan walaupun belum semuanya memmenuhi ketentuan persyaratan minimal dengan predikat baik. Perkembangan kemampuan guru meningkat tajam, dari 30 guru yang dilatih dan dinilai hasilnya sebagai berikut : 5 orang mendapat predikat cukup, 16 orang mendapat predikat baik dan 9 orang mendapat predikat sangat baik. Hasil setiap siklus dalam penelitian ini senantiasa mengalami peningkatan walaupun belum semuanya memenuhi kreteria ketuntasan minimal dengan predikat baik.

\section{Saran}

Berdasarkan simpulan hasil penelitian dan pembahasan, maka kami sampaikan saran sebagai berikut:

1. Kepada guru Pendidikan Agama Hindu agar senantiasa mengikuti KKG/MGMP serta pembinaan dan Pelatihan baik di Gugus di Kecamatan maupun di Kabupaten untuk memperluas dan memperdalam pengetahuan dibidang pendidikan yang terus berkembang.

2. Kepada para pengawas untuk senantiasa melakukan Inovasi teknologi pembelajaran, khususnya yang berhubungan dengan metode peningkatan kualitas guru dengan senantiasa melakukan pelatihan pembuatan RPP di Gugus melalui KKG. Hal ini sesuai dengan hasil penelitian ini yang menunjukan bahwa kegiatan pembinaan dan pelatihan guru dalam membuat RPP Kurikulum 2013 menunjukan hasil yang sangat signifikan.

3. Kepada Sekolah, sebagai lembaga pendidikan formal agar mendorong dan momotivasi Pengawas dan Guru untuk senantiasa meningkatkan kemampuan dan kualitas proses pembelajaran dapat ditingkatkan untuk mencapai hasil belajar yang baik.

\section{DAFTAR PUSTAKA}

Badan Standar Nasional Pendidikan. 2016. Peraturan Menteri Pendidikan dan Kebudayaan Republik Indonesia Nomor 22 Tahun 2016. Jakarta: BSNP.

Depdikbud. 1994. Petunjuk Pelaksanaan Proses Belajar-Mengajar. Jakarta: Direktorat Pendidikan Menengah Umum.

Depdiknas. 1999. Pengelolaan Pengujian Bagi Guru Mata Pelajaran. Jakarta: Direktorat Pendidikan Menengah Umum, Direktorat Jenderal Pendidikan Dasar dan Menengah

Depdiknas, 2003. Undang-Undang Republik Indonesia Nomor 20 Tahun 2003 
tentang Sistim Pendidikan Nasional, Jakarta: Depdiknas.

Depdiknas, 2005. Peraturan Pemerintah Republik Indonesia Nomor 19 Tahun 2005 tentang Standar Nasional Pendidikan, Jakarta: Mendiknas.

Depdiknas, 2006. Pedoman Pelaksanaan Penelitian Tindakan Kelas, Jakarta: Dit Prodik Dirjen PMPTK.

Depdiknas, 2008. Peraturan Pemerintah nomor 74 tentang Guru, Jakarta.

Dwi Agus Sudjimat, 2004. Metodelogi Penelitian, Surabaya: Program Pascasarjana Universitas PGRI Adibuana.

Indrawati dan Maman Wijaya, 2001. Penelitian Tindakan Kelas, Bandung: PPPG IPA Depdiknas.

Netra,Ida Bagus, 1983. Metodologi Penelitian. Singaraja: Biro Perbitan FKIP Unud. 